\title{
The Role of DCX and LIS1 in Migration through the Lateral Cortical Stream of Developing Forebrain
}

\author{
Jilin Bai Raddy L. Ramos Murugan Paramasivam Faez Siddiqi \\ James B. Ackman Joseph J. LoTurco \\ Department of Physiology and Neurobiology, University of Connecticut, Storrs, Conn., USA
}

\section{Key Words}

Doublecortin $\cdot$ Cortex $\cdot$ Migration $\cdot$ Amygdala $\cdot$ Piriform

cortex $\cdot$ Ventral migratory stream

\begin{abstract}
During forebrain development the lateral cortical stream (LCS) supplies neurons to structures in the ventral telencephalon including the amygdala and piriform cortex. In the current study, we used spatially directed in utero electroporation and RNAi to investigate mechanisms of migration to the ventral telencephalon. Cells labeled by in utero electroporation of the lateral ventricular zone migrated into the LCS, and entered the lateral neocortex, piriform cortex and amygdala, where they differentiated primarily as pyramidal neurons. RNAi of DCX or LIS1 disrupted migration into amygdala and piriform cortex and caused many neurons to accumulate in the external and amygdalar capsules. RNAi of LIS1 and DCX had similar as well as distinguishable effects on the pattern of altered migration. Combinatorial RNAi of LIS1 and DCX further suggested interaction in the functions of LIS1 and DCX on the morphology and migration of migrating neurons in the LCS. Together, these results confirm that the LCS contributes pyramidal neurons to ventral forebrain structures and reveals that DCX and LIS1 have important functions in this major migratory pathway in the developing forebrain.

Copyright @ 2008 S. Karger AG, Basel
\end{abstract}

\section{Introduction}

Neural cells of different type and function are often generated from distal germinal zones and then travel along distinct pathways of migration to their final destinations. For example, the pyramidal neurons of the neocortex migrate into position primarily via a radial path from the pallial ventricular (VZ) and subventricular zones, while interneurons migrate primarily tangentially from subpallial sources [Rakic, 1971, 1972; Sidman and Rakic, 1973; Anderson et al., 1997; Tamamaki et al., 1997; Lavdas et al., 1999; Wichterle et al., 2001; Nery et al., 2002; Butt et al., 2005]. Ventral forebrain structures, including nuclei of the amygdaloid complex and piriform cortex, are populated by neurons generated from a specialized zone at the lateroventral pallial VZ near the cortical striatal junction. The migratory pathway traversed by these cells has been termed the lateral cortical stream (LCS) [Bayer et al., 1991] or the ventral migratory stream [Medina et al., 2004]. Although a major pathway of migration in the developing brain, the molecules that direct motility within the LCS are less well understood than those in other migratory pathways in the brain.

Bayer and Altman [1991] provided the first evidence that neurons in the piriform cortex and amygdaloid complex were generated from the VZ near the cortical striatal junction. Other studies have demonstrated that cells gen-

\section{KARGER}

() 2008 S. Karger AG, Basel

Fax +41613061234 E-Mail karger@karger.ch www.karger.com www.karger.com/dne
Dr. Joseph J. LoTurco

Department of Physiology and Neurobiology, University of Connecticut

75 North Eagleville Road, U-3156

Storrs, CT 06269-3156 (USA)

Tel. +1 860486 3271, Fax +1 860486 3303, E-Mail loturco@uconn.edu 
erated from the cortical striatal junction migrate into the LCS along radial glial fibers and migrate to the ventral most forebrain [Austin and Cepko, 1990; Tamamaki et al., 2001]. Distinct compartments of the LCS and the destinations of cells from these compartments have been defined by the overlapping expression pattern of several genes including the transcription factors Tbr1, Lhx 2 and 9, Emx2 and Pax6 [Puelles et al., 2000; Medina et al., 2004; Tole et al., 2005]. In the current study we provide evidence that a TBR1-expressing population of cells in the LCS differentiates as pyramidal neurons in the piriform cortex, lateral neocortex and nuclei of the amygdala.

The cellular mechanisms necessary for neurons to migrate into the ventral forebrain are largely unknown. Both LIS1 and DCX are required for the migration of other neuronal populations [Reiner et al., 1993; des Portes et al., 1998; Gleeson et al., 1998; Hirotsune et al., 1998] and therefore represent good candidates for function in the LCS. Both DCX and LIS1 are needed for nucleokinetic movement and for maintenance of bipolar morphologies in migrating neurons [Bai et al., 2003; Loturco and Bai, 2006; Koizumi et al., 2006; Shu et al., 2004; Tanaka et al., 2004]. DCX and LIS1 proteins interact with each other as well as with distinct sets of protein partners [Sasaki et al., 2000; Coquelle et al., 2002; Tsukada et al., 2003; Gdalyahu et al., 2004; Tanaka et al., 2004; Tsukada et al., 2005]. DCX is also required for neurite extension and branching of neuronal processes [Friocourt et al., 2003; Kappeler et al., 2006], while LIS1 is important for the proliferation of neuronal progenitors [Faulkner et al., 2000; Gambello et al., 2003; Tsai et al., 2005]. DCX and LIS1, therefore, appear to have both shared and distinguishable functions within developing neurons. Such functions are yet to be fully determined at the cellular level in vivo within the same population of migrating neurons. In the current study we have used in utero RNAi as a method to reveal similar, distinct and interdependent effects of LIS1 and DCX loss of function on migrating neurons in the LCS.

\section{Materials and Methods}

\section{RNAi Constructs and Plasmid Vectors}

The mU6pro vector [Yu et al., 2002] was applied for both DCX and LIS1 shRNA vectors used in this study. The hairpin sequence targeting the 3UTR of DCX (mU6pro-DCX3UTRhp) was 5' GCT CAA GTG ACC AAC AAG GCT ATA G 3' [Bai et al., 2003]. The hairpin sequence targeting the coding region of LIS1 (mU6proLIS1) was 5' GAG ATG AAC TAA ATC GAG CTA 3' [Tsai et al., 2005]. These sequences have been previously validated as specific and effective RNAi sequence in 3 previous studies. In the study by Bai et al. [2003], the specific knockdown of DCX protein by
DCX RNAi (mU6pro-DCX3UTRhp) was verified by immunocytochemistry. In the study by Ramos et al. [2006], the migratory defects of neurons caused by mU6pro-DCX3UTRhp were rescued by the overexpression of DCX full-length cDNA. In the study by Tsai et al. [2005], the specific knockdown of LIS1 protein by the LIS1 shRNA sequence used here was verified by Western blot and immunocytochemistry. The cDNAs of enhanced green fluorescence protein (eGFP) and monomeric red fluorescence protein (mRFP) [Campbell et al., 2002] were cloned into pCAGGS vectors between EcoR I site and $B g l$ II site to generate pCAGGS-GFP and pCAGGS-mRFP plasmids, respectively.

\section{In utero Electroporation}

Cells were transfected in vivo by in utero electroporation as described previously [Bai et al., 2003]. Briefly, pregnant rats (Wistar, Charles River, Wilmington, Mass., USA), at 13 and 14 days gestation, were anesthetized intraperitoneally with ketamine/xylazine (100/10 mixture, ketamine, $100 \mathrm{mg} / \mathrm{kg}$, xylazine, $10 \mathrm{mg} /$ $\mathrm{kg})$; the uterine horns were exposed; and plasmids $(1.5 \mu \mathrm{g} / \mu \mathrm{l}$ for siRNA constructs and $0.5 \mu \mathrm{g} / \mu \mathrm{l}$ for pCAGGS-GFP or pCAGGSmRFP as transfection marker) with Fast Green ( $2 \mathrm{mg} / \mathrm{ml}$; Sigma, St. Louis, Miss., USA) were microinjected by pressure (General Valve Picospritzer, Fairfield, N.J., USA) through the uterus into the lateral ventricles of embryos by pulled glass micropipettes. Electroporation was accomplished by discharging a $500-\mu \mathrm{F} \mathrm{ca-}$ pacitor charged to $50-100 \mathrm{~V}$ with a sequencing power supply. The voltage pulse was discharged across a pair of copper alloy oval plates $(1 \times 0.5 \mathrm{~cm})$ placed on either side of the head of each embryo through the uterus. All animal protocols were approved by the University of Connecticut Institutional Animal Care and Use Committee.

Histology and Immunocytochemistry

Embryonic brains were removed and drop fixed with $4 \%$ paraformaldehyde/PBS. After transcardial perfusion, postnatal brains were removed and fixed with $4 \%$ paraformaldehyde/PBS. Freefloating sections $(50 \mu \mathrm{m})$ were obtained with a vibratome (Leica VT1000S) and stained for confocal and light microscopy according to standard protocols. Sections were incubated with primary antibodies (DCX, sc-8066, 1:100, Santa Cruz; GFAP 1:1,000, Sigma; GFP 1:1,000, Chemicon; RFP 1:1,000, Chemicon; NeuN 1:1,000, Chemicon; Nestin, Brn1, Ctip, Oct6 1:200, Chemicon; NG2 1:100, gift of A. Nishiyama, University of Connecticut, Storrs, Conn., USA; Tbr1 1:2,000, gift of R. Hevner, University of Washington, Seattle, Wash., USA) in $0.1 \%$ Triton $\times 100,2.5 \%$ NGS, and $\mathrm{PBS}$ at $4^{\circ} \mathrm{C}$ overnight. For use with light microscopy, sections were rinsed several times with $2.5 \%$ NGS in PBS and then incubated in biotinylated secondary antibodies (biotinylated goat anti-mouse, goat anti-rabbit; 1:200, Vector Labs, Burlingame, Calif., USA) for $2 \mathrm{~h}$ at room temperature. Sections were rinsed several times with PBS and incubated for $1 \mathrm{~h}$ in an avidin-horseradish peroxidase mixture. Sections were rinsed in PBS and then reacted with $0.05 \%$ diaminobenzidine in the presence of $0.0015 \% \mathrm{H}_{2} \mathrm{O}_{2}$. Sections were collected onto gelatin-coated slides, dried for several hours and coverslipped with Cytoseal. Alternatively, secondary antibodies conjugated for various fluorochromes (Alexa 488, 568, 633; goat anti-mouse, goat anti-rabbit; all 1:200, Molecular Probes, Eugene, Oreg., USA) were used for confocal microscopy. In some tissue, nuclei were labeled with TO-PRO-3 (Molecular Probes) or counterstained with Neurotrace Nissl 530/615 (Molecular Probes). 


\section{DiI Labeling}

E17 brains were fixed with $4 \%$ paraformaldehyde/PBS. DiI (1,1'-dilinoleyl-3,3,3',3'-tetramethyl-indocarbocyanine4-chlorobenzenesulfonate) (Molecular Probes) crystals were dissolved in dimethyl sulfoxide (Sigma). The DiI solution was applied onto rectangular lens paper $(7 \times 3 \mathrm{~mm}$; Fisher Scientific). The DiIsoaked lens paper was then laid on the surface of the ventral lateral cortex of fixed brains. In order to keep the lens paper in close contact with the brain surface, $2 \%$ agar was used to embed the whole brain. After 2 weeks of incubation in $4 \%$ paraformaldehyde/PBS at $37^{\circ} \mathrm{C}$, labeled brains were sectioned $(75 \mu \mathrm{m})$ with a vibratome (Leica VT1000S).

\section{Microscopy and Image Analysis}

Images were acquired on a Leica TCS SP2 confocal system $(0.5-$ $1.0 \mu \mathrm{m}$ optical sections) or a Nikon Eclipse 400 with a Spot camera. Images were further processed with Adobe Photoshop CS to adjust color balances and levels. For analysis of transfected cell number and of cell type at postnatal day P21, every transfected cell in 13 coronal sections between bregma $-1.8 \mathrm{~mm}$ and bregma $-5.2 \mathrm{~mm}$ of P21 brains was counted and scored for cell type category. The morphological categories of pyramidal neuron (neocortical, piriform or amygdalar), astrocyte and small bipolar cell were used as they were categorically separable and could account for every transfected cell in the parenchyma. Cells trapped in white matter at P21 in the RNAi conditions were not scored for cell type because morphologies were often atypical and cell densities obscured definitive categorization. The migration distance of cells $(n>2,000$ in each analysis condition) at P21 and E19 was determined with automated particle analyses in Image and plotted in Microsoft Excel. Somas were marked in Photoshop with a point placed in the center of the nucleus and the marks were counted and coordinates determined by automated particle analysis in ImageJ. The length of leading neuronal processes, defined as the distance from the point where the leading process joins soma to the visible end of the leading process, was determined for 50 LCS cells per brain section. Measurements were repeated in at least 4 brains for each conditions. The number of both multipolar cells and radial bipolar cells was counted along the length of the LCS per section, the percentage of multipolar cells in the LCS was subsequently calculated from $>4$ brains for a mean and standard deviation. A multipolar cell was defined as any cell with $>2$ processes protruding directly from the soma. To test for statistical significance in differences between group means, comparisons were made first by 1-way analysis of variance (ANOVA) and then pairwise t test. All coordinates and anatomical area terminology usage follow Paxinos and Watson's [1997] The Rat Brain in Stereotaxic Coordinate and the Atlas of the Developing Rat Nervous System by Paxinos et al. [1994].

\section{Results}

\section{Labeling the LCS by in utero Electroporation}

In order to label and track cells that migrate from the lateral VZ into and through the LCS, we used directed in utero electroporation (fig. 1a). Placement of the positive paddle electrodes to ventrolateral positions across the cerebrum at E13 consistently resulted in transfection of cells in the lateral and ventral aspect of the $\mathrm{VZ}$ at the corticostriatal junction. We found in embryonic rats at E13, unlike results in mice [Borrell et al., 2005], that the lateral or medial ganglionic eminence could not be transfected by electroporation with ventrolateral or even ventral placement of the positive electrode. We do not currently know the reason for this restriction; however, it allowed us to transfect cells at the corticostriatal junction without significant contamination of cells in the ganglionic eminence (fig. 1b).

We first used this method to define the migration trajectory of cells from the transfection site by observing the location of transfected cells 1,3 and 6 days after transfection. One day following transfection, cells were located within the VZ in the lateral neocortex and the corticostriatal junction (fig. 1b) and were nestin-positive and had the typical radial morphologies of radial glia and progenitors (fig. 1c). Three days after transfection some cells had migrated directly along a radial path into the intermediate zone and into the cortical plate of the lateral neocortex, while other cells tracked ventrally along the pallial-subpallial boundary (fig. 1b, double arrowheads). Six days following transfection (E13; E19), a stream of migratory cells extended to a region at the end of the LCS (fig. 1b, triple arrowhead). The transfected cells tracked along a path that was densely labeled for radial glial fibers (nestin+) and DiI labeling showed that such fibers extended to the pial surface of ventral forebrain (fig. 1d). Six days following transfection many transfected cells were found within the piriform cortex and amygdala (fig. 1e).

\section{Labeled LCS Cells Express TBR1 and DCX}

We performed immunocytochemistry on cells in the LCS 4 days following transfection to determine the identity of migrating cells. The hypothesized neuronal identity of the vast majority of transfected cells was confirmed by immunostaining with antibodies against TBR1 and DCX. Nearly $90 \%$ of transfected cells in the LCS were TBR1-immunopositive, a transcription factor identifying postmitotic projection neurons in the neocortex [Bulfone et al., 1995; Hevner et al., 2001], which also identifies a component of the LCS [Puelles et al., 2000]. In addition, approximately $88 \%$ of transfected cells were positive for DCX (fig. 2b). In contrast, we found no transfected cells positive for nestin, GFAP or NG2 in the LCS 4 days after transfection ( $\mathrm{n}=3$ brains/marker approximately 1,000 cells analyzed). The immunocytochemistry results indicate that the cells we have tracked within the LCS are primarily newly generated TBR1- and DCX-expressing neurons. 


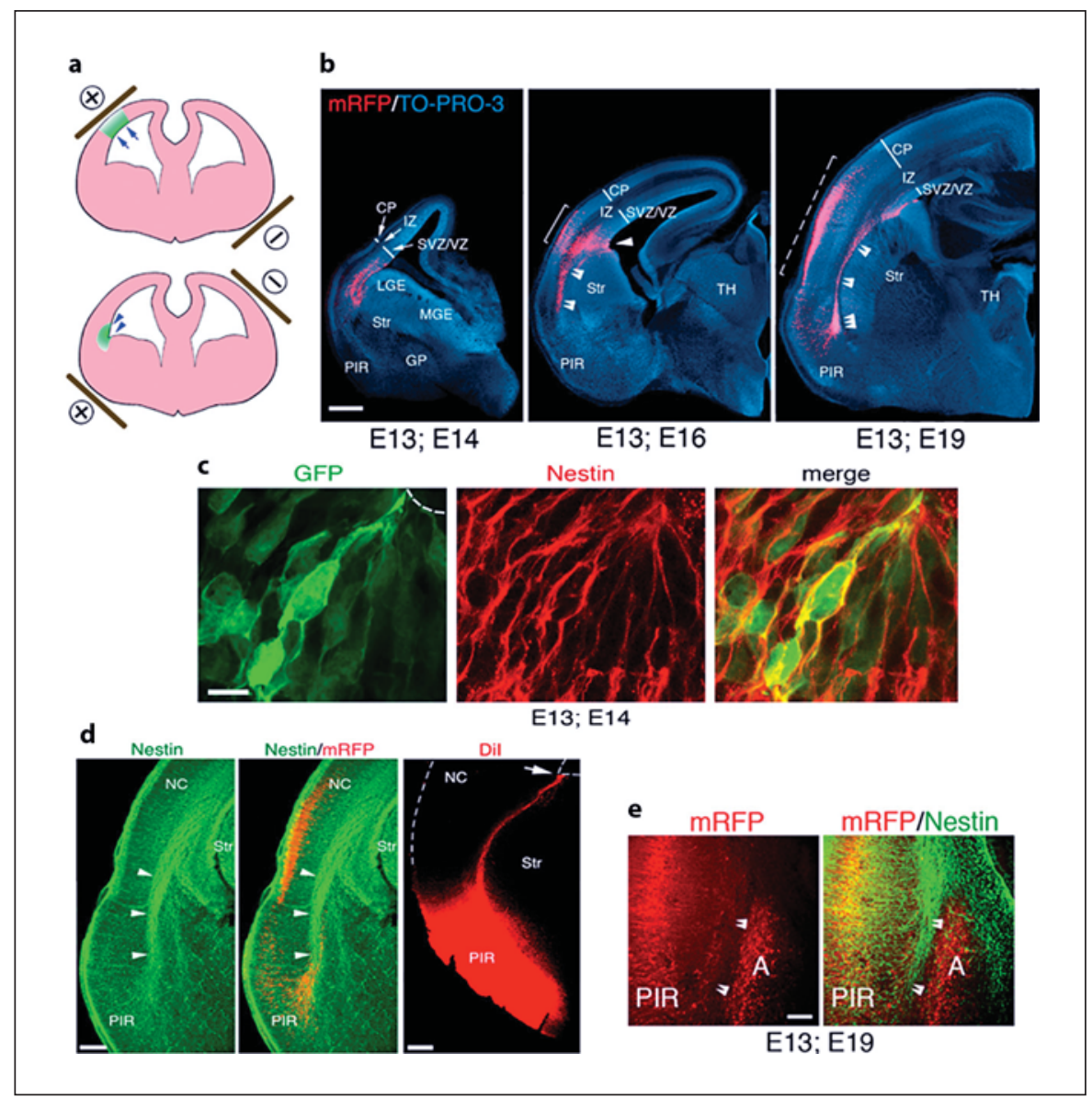

Fig. 1. Directed in utero electroporation labels cells that migrate through the LCS. a Transfection locations in telencephalon resulting from dorsal lateral (top) or ventral lateral (bottom) placement of the positive paddle electrode. $\mathbf{b}$ Transfected cells after ventral lateral transfections 1, 3 and 6 days following transfection at E13. The transfection plasmid in these experiments was PCAGGS-mRFP. By 3 days (E13; E16, middle panel), mRFP-expressing cells spread from the transfection site (arrowhead) along a ventral path (double arrowheads). A subpopulation of $\mathrm{mRFP}^{+}$ cells migrated laterally and reached the cortical plate (solid square bracket). As shown in the right panel (E13; E19) by 6 days after transfection, $\mathrm{mRFP}^{+}$cells are located further along the LCS (double arrowheads), reach a cell reservoir (triple arrowheads) at the ventral most extent and reach superficial neuronal layers along the lateral pallium from neocortex to piriform cortex (dashed

Labeled LCS Cells Give Rise to Neurons in Neocortex, Piriform Cortex and Amygdala

To determine the final destination and fates of LCS cells transfected at E13, we analyzed brains 21 days after birth. By this time fully differentiated neurons were located primarily in the temporal neocortex, piriform cortex and the amygdala (fig. 3b). The labeled neurons in square bracket). Scale bar, $1 \mathrm{~mm}$. c Transfected radial progenitors at the $\mathrm{VZ}$ of the cortical striatal junction 1 day following transfection at E13 are positive for nestin. Scale bar, $15 \mu \mathrm{m}$. d Nestin+ fibers (arrowheads) track along a path similar to the path formed by cells labeled by ventrolateral transfections. DiI placed on the pial surface of piriform cortex labels fibers that track back along the LCS to the corticostriatal junction (arrow). Scale bars, 200 $\mu \mathrm{m}$. e By 6 days after transfection many labeled cells have entered the developing amygdala and the piriform cortex. Scale bar, 100 $\mu \mathrm{m}$. Abbreviations for all figures: $\mathrm{A}=$ Amygdala; $\mathrm{CC}=$ corpus collosum; $\mathrm{CP}=$ cortical plate; $\mathrm{GP}=$ globus pallidus; $\mathrm{HIP}=$ hippocampal region; IZ = intermediate zone; LGE = lateral ganglionic eminence; $\mathrm{MGE}=$ medial ganglionic eminence; $\mathrm{NC}=$ neocortex; PIR = piriform cortex; Str = striatum; SVZ = subventricular zone; $\mathrm{TH}=$ thalamic region.

the temporal neocortex were nearly uniformly pyramidal in morphology $(95 \%, \mathrm{n}=9$ brains; pyramidal somas $\sim 15 \mu \mathrm{m}$ in diameter and long prominent branching apical dendrites with spines). There was a small proportion of labeled atrocytes (3.4\%) and an even smaller proportion of small bipolar cells with round somas $(\sim 6 \mu \mathrm{m}$ in diameter) and thin sparsely branching processes (1.7\%) 
a

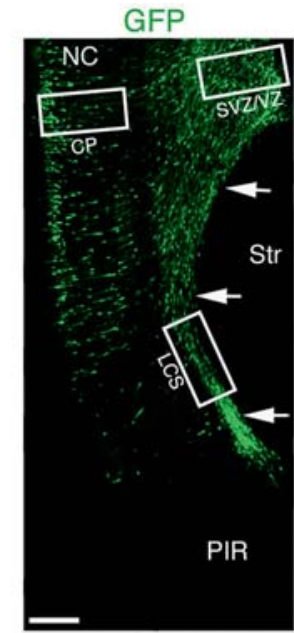

b

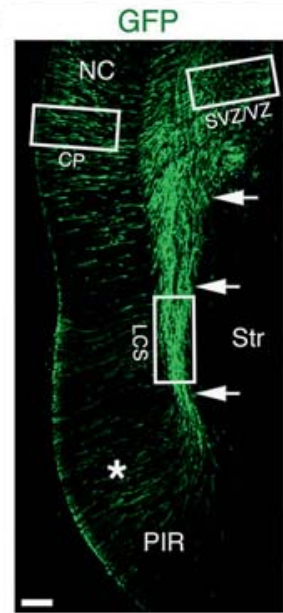

Tbr1

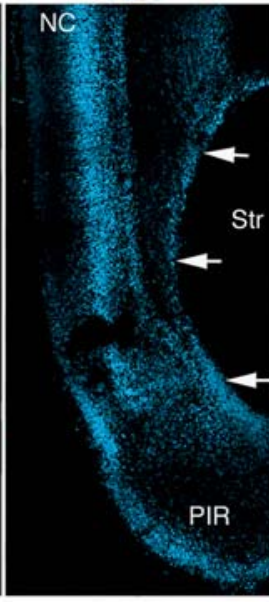

$\mathrm{DCX}$

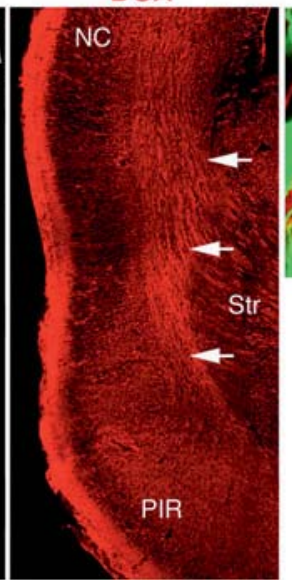

DCX/GFP
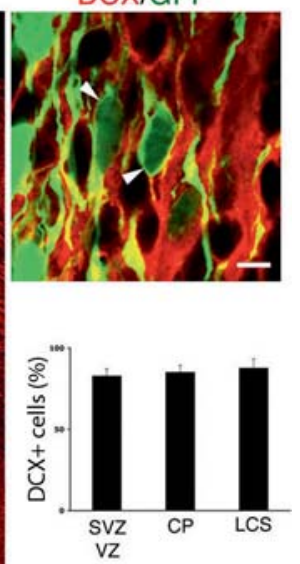

Fig. 2. Migrating neurons in the LCS express TBR1 and DCX. a Immunocytochemistry for TBR 14 days after transfection. In this experiment cells were transfected with pCAGGS-eGFP (left) or pCAGGS-mRFP (right). Images show the stream of transfected cells coextensive with a TBR1 cell stream (arrows). The y-axes of the bar graphs indicate the percentage of transfected (mRFPpositve) cells that were positive for the indicated marker (TBR1 or DCX). Analysis of Tbrl immunopositivity in cells indicates that $(88.7 \pm 6.33 \%)$ of the transfected cells in the LCS were positive for TBR1. The level of positivity was significantly greater than the percentage positivity in the cortical plate of lateral neocortex at the same survival time ( $\mathrm{p}<0.05$, single-factor ANOVA; ${ }^{*} \mathrm{p}<0.05$, paired test, $\mathrm{n}=4$ brains). Scale bars, $200 \mu \mathrm{m}$ (left panel) and $5 \mu \mathrm{m}$ (top right panel). b DCX positivity of cells within the LCS. The transfected stream of cells was coextensive with a ventrally directed DCX-positive cell stream (arrows). Quantification shows that the percentages of cells immunopositive for DCX in the LCS and neocortical cortical plate were similar (LCS, $87.95 \pm 5.40 \%$; $\mathrm{CP}, 85.36 \pm 4.11 \%$ and subventricular zone/intermediate zone $83.02 \pm 4.32 \%) 4$ days after transfection $(n=4)$. Scale bars, 100 $\mu \mathrm{m}$ (left panel), $5 \mu \mathrm{m}$ (right panel). For abbreviations see legend to figure 1 . a

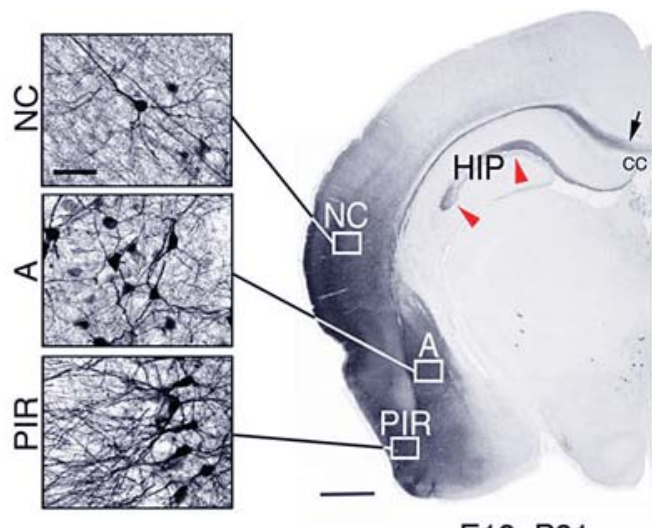

E13; P21 b

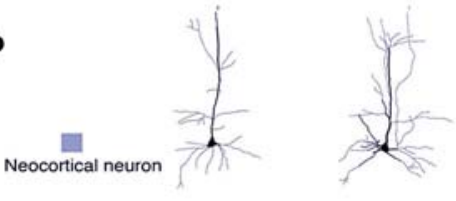

Astrocyte

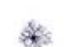

*5.

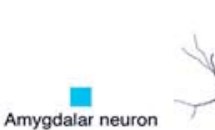<smiles>CC(C)C(C)C</smiles>

-

Smail bipolar cell

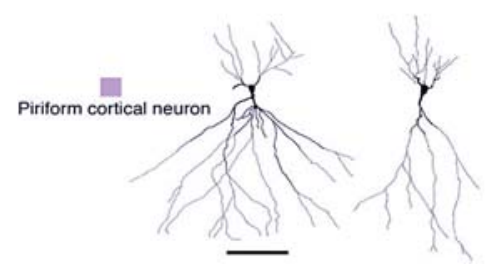

c
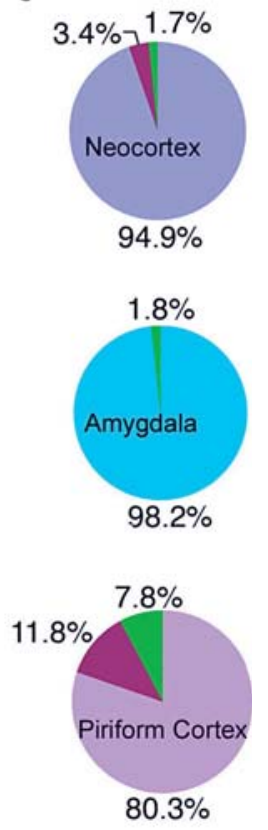

Fig. 3. Transfected LCS cells differentiate as primarily pyramidal neurons in lateral neocortex, piriform cortex and amygdala. a Coronal section at $\mathrm{P} 21$ showing transfected cells located in the lateral neocortex, the amygdala and the piriform cortex. Axons are also labeled and these axons extend into hippocampus (arrowheads) and across the corpus callosum (arrow). Enlarged images (left panels) show the uniformly neuronal morphologies of cells in the lateral neocortex, the amygdala and the piriform cortex. Scale bar, $100 \mu \mathrm{m}$. b Camera lucida reconstructions made from transfected cells illustrate characteristic and categorically different morphologies of major cell types transfected. c Pie graphs show percentages of cell types in each region analyzed. For abbreviations see legend to figure 1 . 
Fig. 4. Immunohistochemical characterization of cell types in $\mathrm{P} 26$ piriform cortex transfected by lateral transfections at E13. a Transfected eGFP+ pyramidal neurons imaged at P26 after an E13 electroporation in layer II of pirform cortex were positive for Brn1 and Tbr1 but were negative for the layer III markers Ctip and Oct6. Scale bar, $75 \mathrm{~mm}$. b Transfected eGFP+ astrocyte in piriform cortex at P26 positive for GFAP imunnohistochemistry. Scale bar, $5 \mathrm{~mm}$. c The small bipolar cells in piriform cortex transfected at E13 were positive for Tbrl but negative for NeuN, the oligodendrocyte precursor marker NG2, and negative for GFAP. Scale bar, $5 \mathrm{~mm}$. a
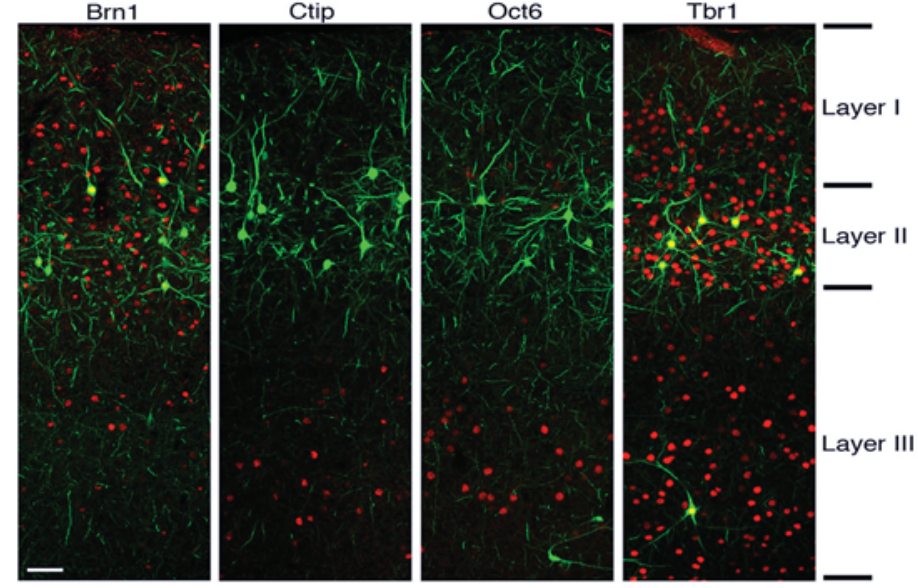

b
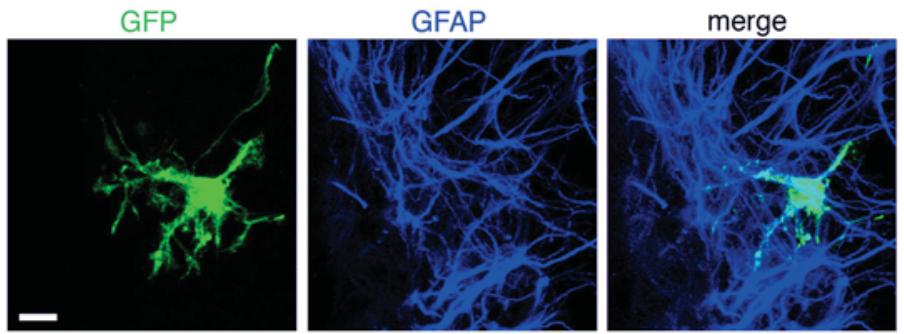

c
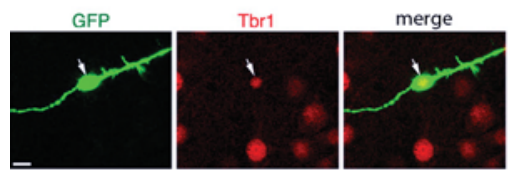

GFP

NeuN

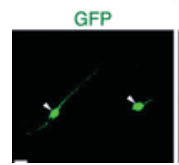

merge

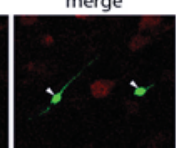

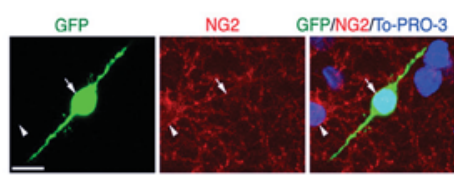

merge

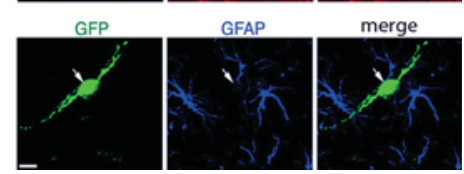

(fig. 3b, c). Labeled neurons in the piriform cortex were primarily localized within layer II and had pyramidal morphologies typical of superficial pyramidal cells [Haberly and Behan, 1983; Haberly and Bower, 1984; Johnson et al., 2000]. The population of transfected cells in the piriform cortex consisted primarily of pyramidal cells with some astrocytes (11.8\%) and small bipolar cells $(7.8 \%)$. No cells with oligodendrocyte morphologies were labeled by the E13 transfections. We further characterized the 3 cell types identified and categorized by morphology with immunocytochemistry. The pyramidal neurons were Brn1- and Tbr1-positive but Ctip- and Oct6-negative (fig. 4a). The astrocytes were GFAP-positive (fig. 4b). The small bipolar cells were negative for GFAP and the oligodendrocyte precursor marker NG2 (fig. 4c), negative for the neuronal marker NeuN, but positive for the neuronal marker TBR1 (fig. 4c).

The amygdaloid complex is made up of several nuclei, and we found neurons following our electroporation within several nuclei of basal and posterior amygdala, including dorsolateral, ventromedial, ventrolateral, basal lateral and basal medial nuclei. We did not find transfected neurons in the nearby dorsal endopiriform nucleus, basolateral anterior, basolateral medial anterior nuclei, or claustrum. For simplicity of analysis we grouped 
a

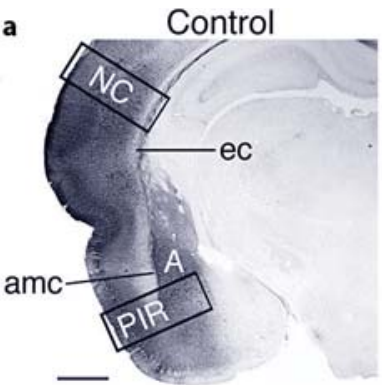

b

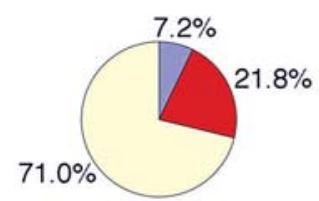

c
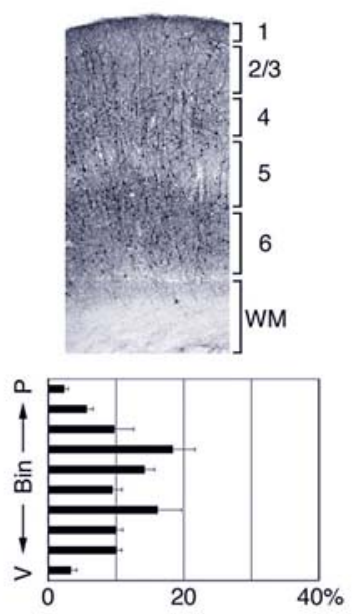

d
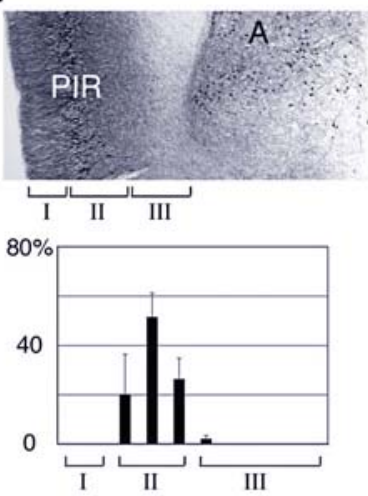
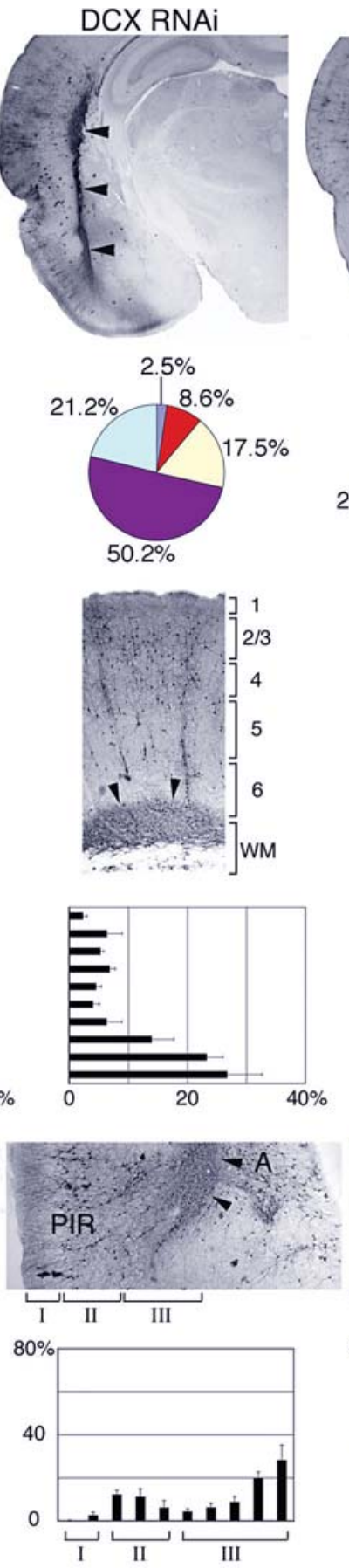
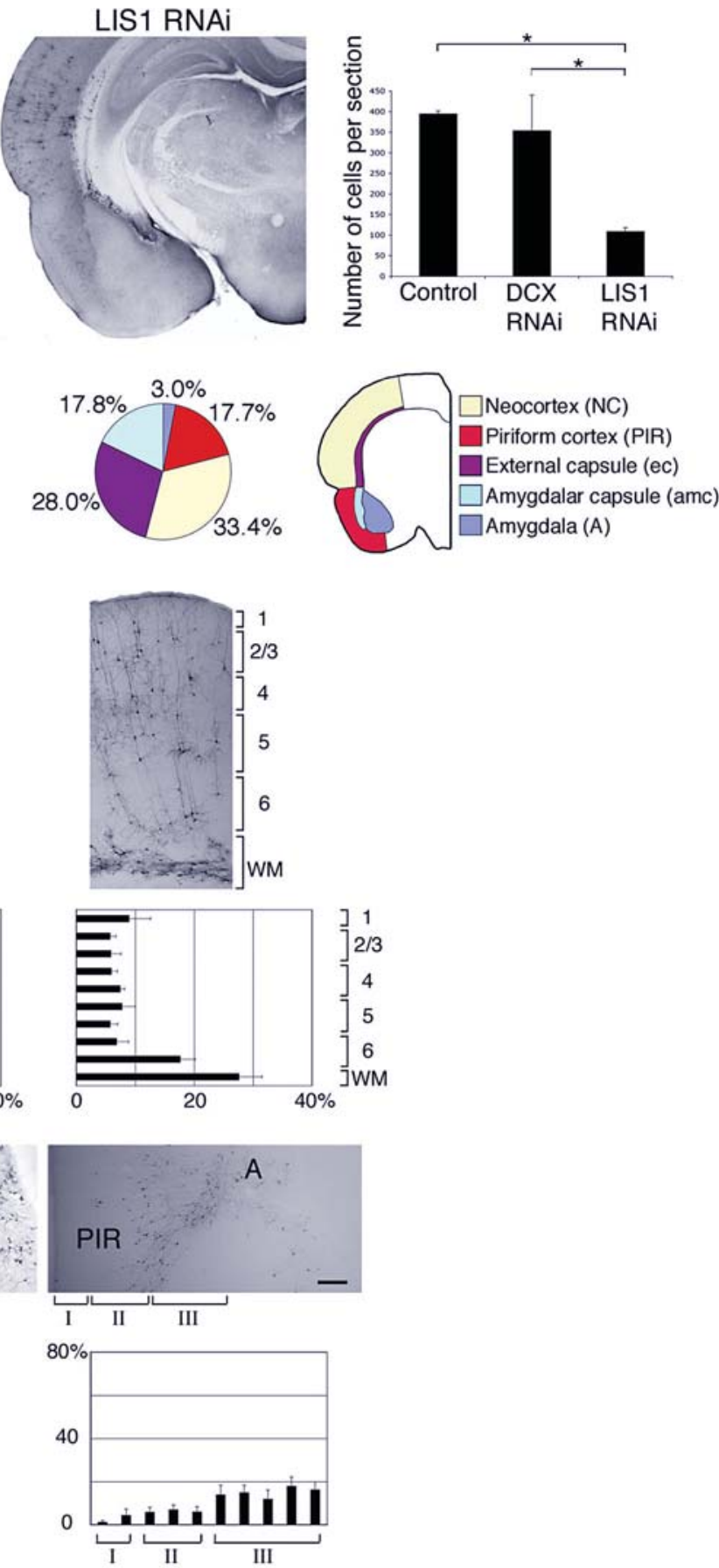

Fig. 5. RNAi of DCX and LIS1 disrupt migration of LCS cells into ventral telencephalon. a Coronal sections of P21 brains. In a control transfected brain, labeled cells were located in the lateral neocortex, amygdala and piriform cortex. In the DCX RNAi transfected brain, labeled cells accumulated along the external capsule (ec) and amygdalar capsule (amc) forming a subcortical band heterotopia (arrowheads). Some labeled cells were scattered in the lateral neocortex, amygdala and piriform cortex. In LIS1 RNAi transfected brain, cells were sparsely scattered in the lateral neocortex, amygdala, piriform cortex, external capsule and amygdalar capsule. Quantification of the total number of cells per section of brain indicates that there were $415.92 \pm 9.72$ labeled cells in control ( $\mathrm{n}=6$ sections of 3 brains) and $353.57 \pm 86.80$ labeled cells in DCX RNAi transfected brains ( $\mathrm{n}=6$ sections of 3 brains), and both are significantly more than $108.85 \pm 9.21$ labeled cells in LIS1 RNAi transfected brains ( $\mathrm{n}=6$ sections of 3 brains). 
all transfected cells within the amygdala. Labeled cells in the amygdala were uniformly neuronal in morphology and were almost exclusively of a morphology typical of class I pyramidal projection neurons [Haberly and Behan, 1983; Haberly and Bower, 1984; McDonald, 1985; Washburn and Moises, 1992; Rainnie et al., 1993; Johnson et al., 2000]. The amygdala also contained a very small proportion $(1.8 \%)$ of transfected cells that were small bipolar cells, but there were no labeled astrocytes in the amygdala of any of the 9 brains analyzed. The relative occurrence of the transfected cell types in lateral neocortex, piriform cortex and amygdala are shown in figure 3. Notably, transfections overwhelmingly labeled pyramidal type neurons in all areas. Consistent with a lack of transfected interneurons following electroporation of neocortical VZ [Ramos et al., 2006], we found no transfected cells in ventral telencephalon that were immunopositive for interneuron markers parvalbumin, calretinin or $\mathrm{GAD}(\mathrm{n}=3$ brains analyzed).

\section{DCX and LIS1 RNAi Disrupt Migration into Piriform} Cortex and Amygdala

To determine whether DCX and LIS1 play a role in ventral migration we used in utero RNAi to target DCX and LIS1 expression. Both LIS1 and DCX have been previously targeted by RNAi in neocortex, and we used the same shRNA vectors as in these previous studies. The 2 shRNA constructs we used were validated in assays of protein expression knockdown in vivo and in vitro [Bai et al., 2003; Tsai et al., 2005], by point mutation controls and, in the case of DCX RNAi, by rescue of the impaired migration phenotype [Ramos et al., 2006].

$\mathrm{p}<0.01$, single-factor ANOVA; ${ }^{*} \mathrm{p}<0.05$, paired t test. Error bar, SEM. Scale bar, $2 \mathrm{~mm}$. b Schematic diagram and pie graphs show the percentage of cells in each designated region. c Higher magnification shows abnormal positioning of labeled cells in the neocortex resulting from RNAi of DCX and LIS1. Labeled cells that migrated into the neocortex of both DCX RNAi and LIS1 RNAi transfected brains aberrantly scattered through neuronal layers. $\mathrm{WM}=$ White matter; $\mathrm{V}=$ ventricle; $\mathrm{P}=$ pia. $\mathbf{d}$ Higher magnification shows abnormal positioning of labeled cells in the piriform cortex and amygdala resulting from RNAi of DCX and LIS1. In control, labeled cells concentrated within layer II of piriform cortex. In the DCX RNAi transfected brain, labeled cells were scattered in all 3 layers of the piriform cortex. In the LIS1 RNAi transfected brain, labeled cells were much smaller and scattered in the piriform cortex and into amygdala. Scale bar, $200 \mu \mathrm{m}(\mathbf{c}, \mathbf{d})$.

DCX and LIS1 in the Lateral Cortical Stream
As shown in figure 5 , ventrolateral electroporation at E13 of shRNAs directed against DCX or LIS1 created impairments in migration to temporal neocortex, piriform cortex and amygdala. In all 6 brains analyzed DCX RNAi caused cells to accumulate along the length of external capsule and amygdalar capsule, forming a prominent subcortical band heterotopia (fig. 5a, arrowheads). LIS1 RNAi caused a substantial decrease in the number of labeled cells (fig. 5a), and similar to DCX RNAi, transfected cells were aberrantly accumulated in the external capsule and amygdalar capsule $(n=6$; fig. $5 a, b)$. Unlike DCX RNAi, a large subcortical band heterotopia did not form in any of the 6 brains after LIS1 RNAi, although many neurons were trapped within white matter (fig. 5c). DCX and LIS1 RNAi also caused disruption in laminar position (fig. 5c, d). After LIS1 and DCX RNAi, cells were displaced towards the white matter in temporal neocortex and piriform cortex (fig. 5c).

\section{DCX and LIS1 RNAi Disrupt Normal Radial and}

Horizontal Migration in Embryonic Forebrain

In order to further compare the roles of DCX and LIS1 in migration in the LCS we measured both radial (fig. 6a, solid arrow) and ventral positions of cells 6 days after transfection. We chose 6 days for an early analysis because this is the earliest time after transfection that control transfected cells have spread along the full extent of the LCS and have begun to enter the piriform cortex and amygdala (fig. 1b, d). Radial position was determined as the distance of each cell in the LCS or cortex from the VZ surface (in more dorsal aspects) and from the pallial/subpallial boundary (in ventral aspects). Ventral position was determined as the distance of cells ventrally from a line drawn from the corticostriatal junction to the pial surface. The average ventral position of control cells was $1,337.0 \pm 94.25 \mu \mathrm{m}$ and the average radial position was $469.91 \pm 70.39 \mu \mathrm{m}(\mathrm{n}=13$ brains; fig. $6 a, b)$. In contrast, the average ventral and radial position of DCX-RNAi-treated cells was significantly less than controls (995.06 $\pm 61.76 \mu \mathrm{m}$ and $243.04 \pm 44.28$ $\mu \mathrm{m} ; \mathrm{n}=12$ brains; fig. $6 \mathrm{a}, \mathrm{b}$ ). Similarly, the average ventral position of LIS1-RNAi-treated cells was $948.42 \pm$ $55.77 \mu \mathrm{m}$ and radial was $328.82 \pm 53.69 \mu \mathrm{m}(\mathrm{n}=11$ brains; fig. 6a, b). Quantitatively, the pattern of migration disruption was similar and not statistically different for LIS1 and DCX RNAi conditions. The one conspicuous qualitative difference between LIS1 RNAi and DCX RNAi 6 days after transfection was that in all brains in the LIS1 RNAi condition there were increased radial glial fibers that extended along the LCS to the pial 
Fig. 6. Impaired radial and ventral migration in embryonic brain. a DCX RNAi, LIS1 RNAi and the combination of DCX RNAi and LIS1 RNAi disrupted radial migration (arrows) and ventral migration (dotted arrow) measured 6 days following ventrolateral transfection. LIS1 RNAi gave rise to prominent eGFP+ fibers spanning the LCS and the CP (arrowheads). These fibers formed terminal arborizations (asterisks) in the marginal zone. Scale bar, $200 \mu \mathrm{m}$. b Bar graphs show quantification of radial and ventral migration distances in 4 conditions. Day 6 control $(n=13$ brains, repeated in 5 different litters), DCX RNAi ( $\mathrm{n}=12$ brains, repeated in 6 different litters), LIS1 RNAi ( $\mathrm{n}=11$ brains, repeated in 5 different litters), DCX RNAi + LIS1 RNAi ( $\mathrm{n}=5$ brains, repeated in 2 different litters). All 3 RNAi conditions significantly impaired radial and ventral migration to a similar extent relative to control. $\mathrm{p}<0.01$, single-factor ANOVA; post hocs, ${ }^{*} \mathrm{p}<0.05,{ }^{* *} \mathrm{p}<0.01$, paired $\mathrm{t}$ test. Error bar, SEM.

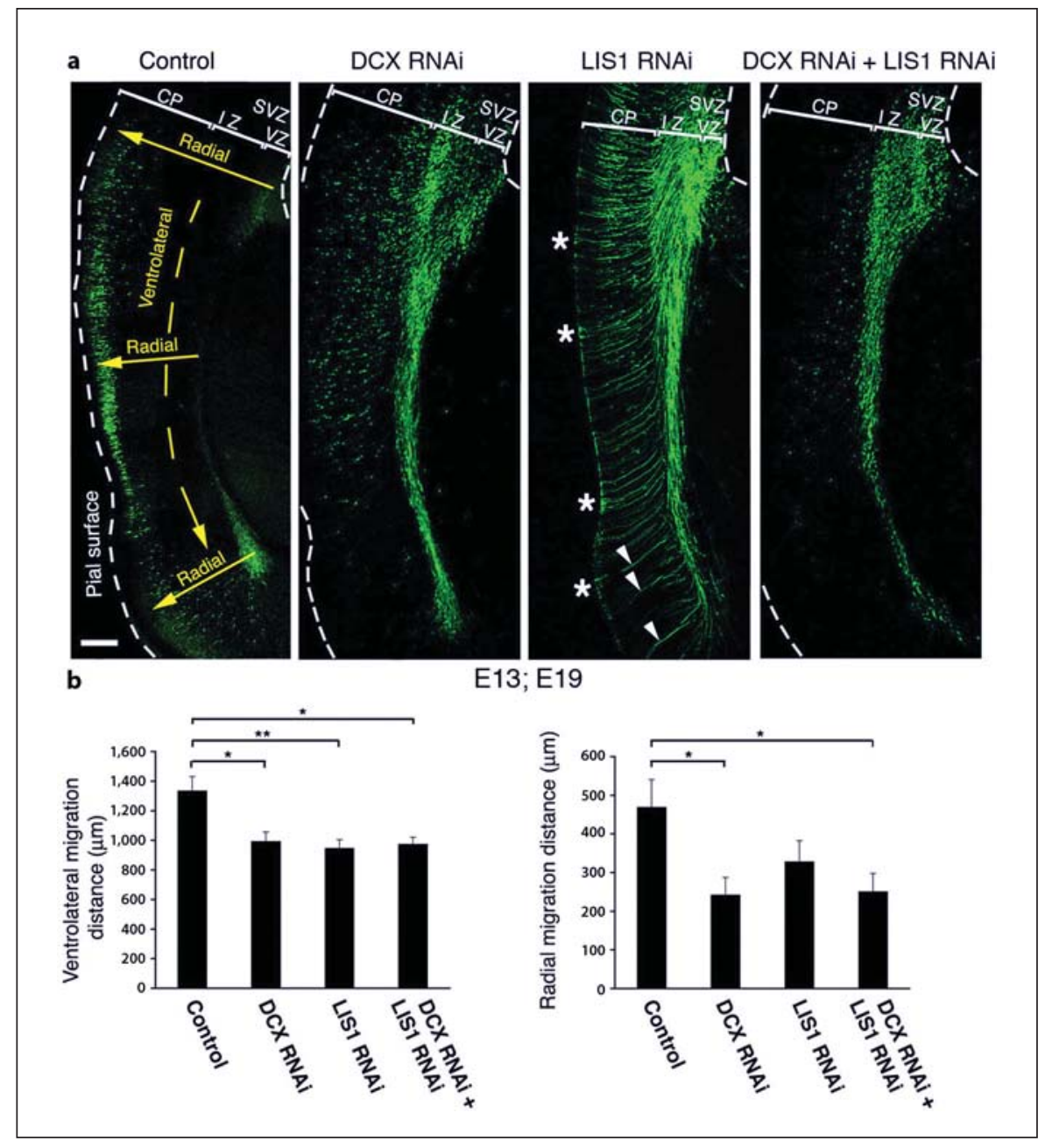

surface. These fibers were confirmed as radial glial/progenitors by immunopositivity for nestin and vimentin but negative for GFAP, DCX and MAP2. The large numbers of cells that migrated into the LCS in LIS1 RNAi conditions were not nestin-positive, but DCX-positive, and so do not account for the maintained glial fiber population.

To further investigate the functional relationships between LIS1 and DCX we used combinatorial RNAi in which DCX and LIS1 shRNA plasmids were cotransfected. Similar to either RNAi treatment alone, the average ventral and radial position of cells following combined RNAi was $976.19 \pm 44.09 \mu \mathrm{m}$ and $251.53 \pm 46.57 \mu \mathrm{m}$, respectively ( $\mathrm{n}=5$ brains; fig. $7 \mathrm{a}, \mathrm{b}$ ). The 2 RNAi treatments combined together, therefore, neither additively nor synergistically impaired migration relative to either RNAi alone. In addition, the combinatorial RNAi did not result in the maintained radial progenitor phenotype that resulted from LIS1 RNAi alone (fig. 6a).

\section{DCX and LIS1 Are Required for Maintaining \\ Migrating Neuronal Morphologies in the LCS}

Both DCX and LIS1 have been shown to play a role in maintaining the bipolar morphology of migrating cells in radial migration paths in the neocortex and in the rostral migratory stream [Bai et al., 2003; Shu et al., 2004; Tsai et al., 2005; Koizumi et al., 2006]. To determine the effects of DCX and LIS1 RNAi on the morphology of migrating neurons in the LCS, we compared the length of the leading process of labeled cells and the percentages of cells that were bipolar or multipolar in each condition 4 days after transfection. As shown in figure 6, LIS1 and DCX RNAi had differential and interdependent effects on cell morphology. First, whereas the leading process of control 
Fig. 7. RNAi of DCX and LIS1 differentially and interdependently alter the morphology of migrating neurons in the LCS. a Morphology of labeled neurons in the LCS 4 days following 4 different transfection conditions: control (eGFP alone, pCAGGS-eGFP); DCX RNAi, LIS1 RNAi and LIS1 + DCX RNAi. b Bar graphs showing quantification of morphologies of cells: leading process length of bipolar cells (b) and percentage of multipolar cells (c) in the LCS following the 4 transfection conditions. $n>600$ cells per condition from 4 brains. $p<0.001$, single-factor ANOVA for leading process length and percent multipolar; post hocs comparing pairs of conditions, ${ }^{*} \mathrm{p}<0.05,{ }^{* *} \mathrm{p}<0.01,{ }^{* * *} \mathrm{p}<0.001$, paired t test. All error bars, SEM. Scale bars in a: $20 \mu \mathrm{m}$ for control and LIS1 RNAi, $10 \mu \mathrm{m}$ for control inset, DCX RNAi and DCX RNAi + LIS1 RNAi, and $5 \mu \mathrm{m}$ for higher magnification insets.

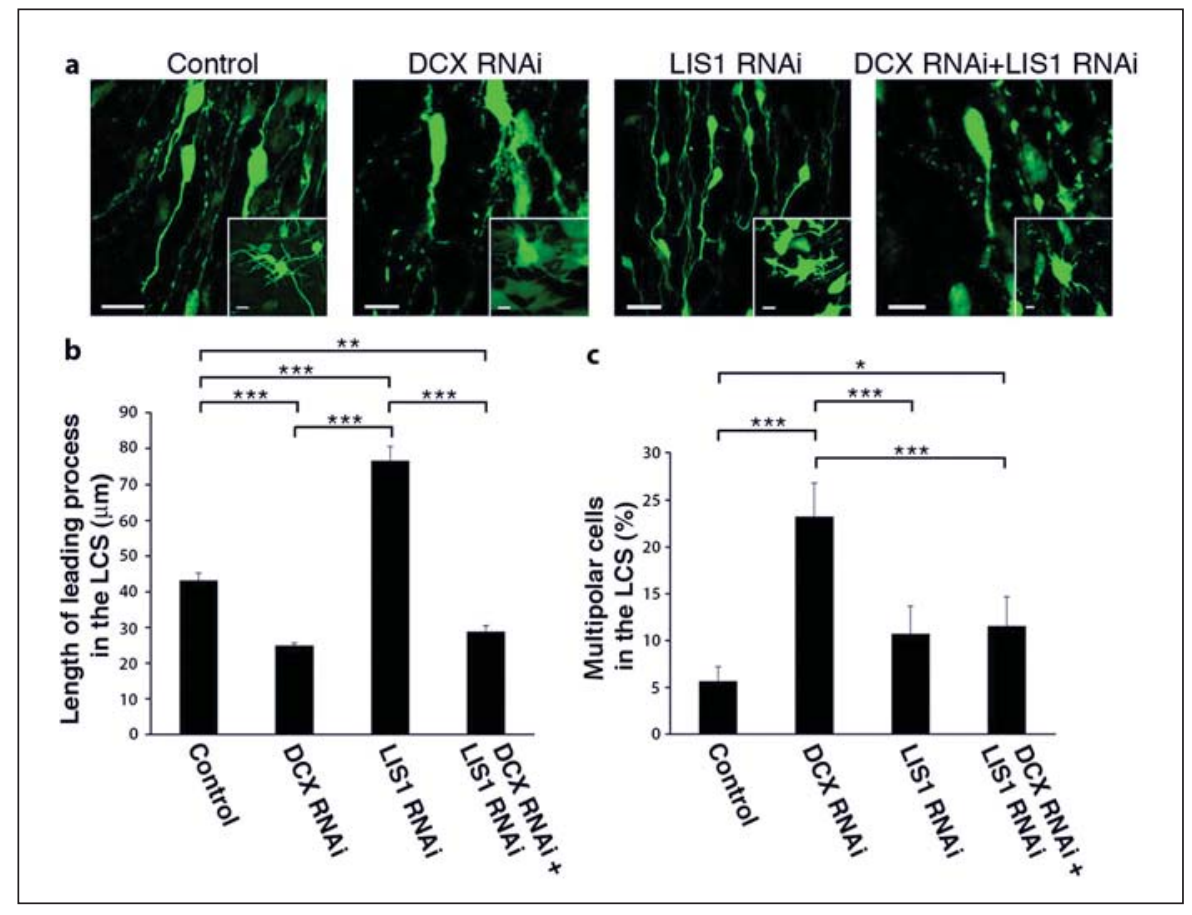

transfected neurons had a mean length of $43.23 \pm 2.05$ $\mu \mathrm{m}$ ( $\mathrm{n}=13$ brains), the leading process of DCX RNAi transfected neurons had significantly shorter leading processes ( $24.97 \pm 0.69 \mu \mathrm{m}, \mathrm{n}=12$ brains; fig. 7$)$. In contrast, the leading processes of neurons affected by LIS1 RNAi $(76.56 \pm 3.98 \mu \mathrm{m} ; \mathrm{n}=11$ brains $)$ were significantly longer relative to controls. Moreover, the significantly longer neurites following LIS1 RNAi were reversed by DCX RNAi: transfection of both shRNAs resulted in a mean leading process length of $28.88 \pm 1.61 \mu \mathrm{m}(\mathrm{n}=5)$, a value comparable to DCX RNAi alone (fig. $7 \mathrm{~b}$ ).

In the LCS, unlike the direct radial path of migration in the neocortex where $35-50 \%$ of cells are in multipolar modes [Tabata and Nakajima, 2003], we found that only $5.7 \pm 0.8 \%$ of cells had multipolar morphologies (fig. 7). In LIS1 RNAi-transfected brains, there was a nearly 2fold increase in the percentage of multipolar cells in the LCS (10.7 $\pm 1.5 \%)$, and in DCX RNAi-transfected brains there was a $>4$-fold increase in the percentage of multipolar cells $(23.3 \pm 1.8 \%$; fig. $7 \mathrm{a}, \mathrm{c})$. The combination of DCX RNAi and LIS1 RNAi resulted in $11.6 \pm 1.6 \%$ multipolar cells, a level similar to LIS1 RNAi alone (fig. 7). Thus, the increase in multipolar cells created by DCX RNAi may be dependent upon LIS1 function, and the increased leading process length created by LIS1 RNAi is dependent upon DCX function.

DCX and LIS1 in the Lateral Cortical Stream

\section{Discussion}

In this study we have tracked a population of labeled cells from the ventral and lateral pallium into the mature amygdala and piriform cortex, and have shown a role for DCX and LIS1 in migration along this pathway. Our results are consistent with interpretations of the LCS based on birthdate labeling and gene expression studies which indicated that the ventral telencephalon is populated by neurons that migrate from the lateral $\mathrm{VZ}$ and cortical striatal junction along the LCS [Bayer et al., 1991; Puelles et al., 2000; Medina et al., 2004]. In addition, our results show that TBR1-expressing cells in the LCS are likely to differentiate as pyramidal type neurons in the ventral forebrain, and that interneurons of the piriform cortex and amygdala are most likely generated from a different population of precursors. Furthermore, we determined that DCX and LIS1 play an important role in migration into structures of the ventral telencephalon.

\section{The LCS Migratory Pathway}

Our study, consistent with other studies, defines properties of the LCS that distinguish it as a major pathway of migration to the ventral forebrain. We found that $90 \%$ of cells transfected expressed TBR1. In contrast, cells migrating out of the VZ and subventricular zone along the

Dev Neurosci 2008;30:144-156 
direct radial path to the dorsal neorocortex do not attain full TBR1 positivity until after they enter the cortical plate [Hevner et al., 2001]. Previous studies have shown that the LCS is composed of distinct domains defined by expression of the transcription factors Tbr1, $\operatorname{Lh} \times 9, \operatorname{Lh} \times 2$, Emx2 and Pax6 [Puelles et al., 2000; Medina et al., 2004; Tole et al., 2005]. We show in this study that cells labeled at the pallial VZ that migrate into the LCS are nearly uniformly TBR1-positive and differentiate as pyramidal neurons. This suggests that pyramidal neurons of the ventral telencephalon, like those of the dorsal and lateral neocortex, originate from the pallial VZ. Our results also support a model that TBR1-negative components of the LCS may derive from ganglionic eminence and may become inhibitory interneurons to the piriform cortex and amygdala.

\section{DCX and LIS1 Are Required for Maintaining Neuronal Morphologies}

We found that DCX and LIS1 RNAi both significantly increase the percentage of multipolar cells in the LCS and differentially affect the length of the leading processes of migrating cells with bipolar morphologies. The first finding is in agreement with previously observed increases of cells with multipolar phenotypes following RNAi of DCX [Bai et al., 2003] and LIS1 [Tsai et al., 2005] in the developing neocortex, and with increases in multipolar migratory cells in the RMS of DCX null mutant mice [Koizumi et al., 2006]. Similarly, aberrant multipolar morphologies of migrating cells have been shown after disruption of filamin A [Nagano et al., 2004]. A challenge of future studies will be to determine whether interruption in the multipolar mode causes migration disruption or a disruption in migration results in a default to multipolar morphologies. Our studies further indicate that even in a pathway of migration that is dominated by bipolar migratory cells such as the LCS, LIS1 and DCX function are required for maintaining normal levels of bipolar morphologies. On the other hand, since DCX and LIS1 RNAi never increased the proportion of multipolar cells in the LCS to $>25 \%$, and yet impaired the migration of the majority of cells into the piriform cortex and amygdala, LIS1 and DCX must also function importantly in bipolar modes of migration in the LCS.

\section{LIS1 Function and Radial Glia}

We observed a unique radial glia phenotype following LIS1 RNAi not previously reported for LIS1 loss of function. While in control brains we found that radial glial fibers associated with transfected cells decreased signifi- cantly over time, presumably due to loss of marker expression following cell division and transition into migrating neurons, some radial glia that extend fibers were maintained after transfection with LIS1 RNAi even 6 days following transfection. This can be viewed as consistent with previous studies showing that loss of LIS1 function slows the cell cycle and blocks interkinetic nuclear migration of radial progenitors [Gambello et al., 2003; Tsai et al., 2005]. One interpretation of our LIS1 RNAi results is that some radial glia that are initially transfected and extend through the LCS are stalled in the progenitor state and then maintain their radial processes after knockdown of LIS1. Interestingly, a combination of DCX RNAi and LIS1 RNAi blocked the aberrant gain of radial glial cell fibers caused by LIS1 RNAi alone. This dependence on DCX might indicate that either DCX functions within aberrant radial progenitors or that DCX function in migrating neurons has an indirect effect on radial glial fibers. We tested for DCX expression in persistent radial glial fibers caused by LIS1 RNAi and in control radial glia, and as expected from multiple previous studies showing that DCX is expressed in postmitotic neurons and not in radial progenitors, we did not detect DCX expression in radial glia. The most likely explanation, therefore, is that there is an indirect effect of DCX function on radial glia. Previously we have described a non-cell-autonomous influence of DCX on other migrating neurons [Bai et al., 2003; Ramos et al., 2006], and this current result may indicate an indirect effect on radial glia.

\section{Interdependent and Reciprocal Functions of LIS1 and $D C X$}

Similarities and differences in the effects of $D C X$ and LIS1 mutations, at both the whole brain and cellular levels, indicate that each gene has overlapping and distinct functions in human brain development [Pilz et al., 1998; Forman et al., 2005]. Our RNAi results further reveal connections and distinctions between the functions of the two. First the decreases in ventral and lateral migration 6 days following RNAi of DCX and LIS1 RNAi were similar in magnitude and were not additive. Thus the loss of function of one appears to preclude additional loss of function, at least in initial migration. A maximum migration disruption (ceiling effect) cannot explain the lack of an additive effect in this case because we have found that DAB1 RNAi (unpubl. observation) can disrupt migration ventrally along the LCS much more severely than either LIS1 or DCX RNAi alone.

Additional new support for functional interdependence between DCX and LIS1 in migration comes from 
our results on the morphologies of LCS cells in combinatorial RNAi experiments. A suppression of one RNAi effect on the other was evident by both the block in the increase in multipolar cells following DCX RNAi and, similarly, by the block of the increased length of leading processes after LIS1 RNAi. This may be explained partially by a model proposed in previous studies [Tanaka et al., 2004; Tsai and Gleeson, 2005; Kappeler et al., 2006]. The longer leading process length of cells following LIS1 RNAi may result from slowed nucleokinesis and somal translocation along an extending leading process. DCX has been previously shown to be important to process extension [Deuel et al., 2006; Kappeler et al., 2006] and
RNAi of DCX decreases the leading process length and also suppresses the increased process length created by LIS1 RNAi. The leading process length of cells in the LCS may thus be determined by a balance of LIS1 and DCX function, by coordinating process extension and somal translocation.

\section{Acknowledgments}

We thank Roger Tsien for mRFP plasmid, Dr. David Turner for mU6pro plasmid and Dr. Akiko Nishiyama for NG2 antibody. This research was supported by the National Institute of Mental Health (MH056524).

\section{References}

-Anderson SA, Eisenstat DD, Shi L, Rubenstein JL (1997): Interneuron migration from basal forebrain to neocortex: dependence on Dlx genes. Science 278:474-476.

-Austin CP, Cepko CL (1990): Cellular migration patterns in the developing mouse cerebral cortex. Development 110:713-732.

Bai J, Ramos RL, Ackman JB, Thomas AM, Lee RV, LoTurco JJ (2003): RNAi reveals doublecortin is required for radial migration in rat neocortex. Nat Neurosci 6:1277-1283.

Bayer SA, Altman J (1991): Development of the endopiriform nucleus and the claustrum in the rat brain. Neuroscience 45:391-412.

- Bayer SA, Altman J, Russo RJ, Dai XF, Simmons JA (1991): Cell migration in the rat embryonic neocortex. J Comp Neurol 307:499516.

- Borrell V, Yoshimura Y, Callaway EM (2005): Targeted gene delivery to telencephalic inhibitory neurons by directional in utero electroporation. J Neurosci Methods 143:151158.

Bulfone A, Smiga SM, Shimamura K, Peterson A, Puelles L, Rubenstein JL (1995): T-brain-1: a homolog of Brachyury whose expression defines molecularly distinct domains within the cerebral cortex. Neuron 15:63-78.

- Butt SJB, Fuccillo M, Nery S, Noctor S, Kriegstein A, Corbin JG, Fishell G (2005): The temporal and spatial origins of cortical interneurons predict their physiological subtype. Neuron 48:591-604.

-Campbell RE, Tour O, Palmer AE, Steinbach PA, Baird GS, Zacharias DA, Tsien RY (2002): A monomeric red fluorescent protein. Proc Natl Acad Sci USA 99:7877-7882.

Coquelle FM, Caspi M, Cordelières FP, Dompierre JP, Dujardin DL, Koifman C, Martin P, Hoogenraad CC, Akhmanova A, Galjart N, De Mey JR, Reiner O (2002): LIS1, CLIP170 's key to the dynein/dynactin pathway. Mol Cell Biol 22:3089-3102.
Des Portes V, Pinard JM, Billuart P, Vinet MC, Koulakoff A, Carrié A, Gelot A, Dupuis E, Motte J, Berwald-Netter Y, Catala M, Kahn A, Beldjord C, Chelly J (1998): A novel CNS gene required for neuronal migration and involved in X-linked subcortical laminar heterotopia and lissencephaly syndrome. Cell 92:51-61.

Deuel TAS, Liu JS, Corbo JC, Yoo S-Y, Rorke-Adams LB, Walsh CA (2006): Genetic interactions between doublecortin and doublecortin-like kinase in neuronal migration and axon outgrowth. Neuron 49:41-53.

Faulkner NE, Dujardin DL, Tai CY, Vaughan KT, O'Connell CB, Wang Y, Vallee RB (2000): A role for the lissencephaly gene LIS1 in mitosis and cytoplasmic dynein function. Nat Cell Biol 2:784-791.

Forman MS, Squier W, Dobyns WB, Golden JA (2005): Genotypically defined lissencephalies show distinct pathologies. J Neuropathol Exp Neurol 64:847-857.

-Friocourt G, Koulakoff A, Chafey P, Boucher D, Fauchereau F, Chelly J, Francis F (2003): Doublecortin functions at the extremities of growing neuronal processes. Cereb Cortex 13:620-626.

Gambello MJ, Darling DL, Yingling J, Tanaka T, Gleeson JG, Wynshaw-Boris A (2003): Multiple dose-dependent effects of Lis1 on cerebral cortical development. J Neurosci 23: $1719-1729$.

- Gdalyahu A, Ghosh I, Levy T, Sapir T, Sapoznik S, Fishler Y, Azoulai D, Reiner O (2004): DCX, a new mediator of the JNK pathway. EMBO J 23:823-832.

- Gleeson JG, Allen KM, Fox JW, Lamperti ED, Berkovic S, Scheffer I, Cooper EC, Dobyns WB, Minnerath SR, Ross ME, Walsh CA (1998): Doublecortin, a brain-specific gene mutated in human X-linked lissencephaly and double cortex syndrome, encodes a putative signaling protein. Cell 92:63-72.
Haberly L, Behan M (1983): Structure of the piriform cortex of the opossum. III. Ultrastructural characterization of synaptic terminals of association and olfactory bulb afferent fibers. J Comp Neurol 219:448-460.

Haberly LB, Bower JM (1984): Analysis of association fiber system in piriform cortex with intracellular recording and staining techniques. J Neurophysiol 51:90-112.

- Hevner RF, Shi L, Justice N, Hsueh Y, Sheng M, Smiga S, Bulfone A, Goffinet AM, Campagnoni AT, Rubenstein JL (2001): Tbrl regulates differentiation of the preplate and layer 6. Neuron 29:353-366.

-Hirotsune S, Fleck MW, Gambello MJ, Bix GJ, Chen A, Clark GD, Ledbetter DH, McBain CJ, Wynshaw-Boris A (1998): Graded reduction of Pafahlb1 (Lis1) activity results in neuronal migration defects and early embryonic lethality. Nat Genet 19:333-339.

-Johnson DM, Illig KR, Behan M, Haberly LB (2000): New features of connectivity in piriform cortex visualized by intracellular injection of pyramidal cells suggest that 'primary' olfactory cortex functions like 'association' cortex in other sensory systems. J Neurosci 20:6974-6982.

Kappeler C, Saillour Y, Baudoin J-P, Tuy FPD, Alvarez C, Houbron C, Gaspar P, Hamard G, Chelly J, Métin C, Francis F (2006): Branching and nucleokinesis defects in migrating interneurons derived from doublecortin knockout mice. Hum Mol Genet 15:13871400.

Koizumi H, Higginbotham H, Poon T, Tanaka T, Brinkman BC, Gleeson JG (2006): Doublecortin maintains bipolar shape and nuclear translocation during migration in the adult forebrain. Nat Neurosci 9:779-786. 
-Lavdas AA, Grigoriou M, Pachnis V, Parnavelas JG (1999): The medial ganglionic eminence gives rise to a population of early neurons in the developing cerebral cortex. J Neurosci 19:7881-7888.

Loturco JJ, Bai J (2006): The multipolar stage and disruptions in neuronal migration. Trends Neurosci 29:407-413.

McDonald AJ (1985): Morphology of peptidecontaining neurons in the rat basolateral amygdaloid nucleus. Brain Res 338:186191.

-Medina L, Legaz I, Gonzalez G, De Castro F, Rubenstein JL, Puelles L (2004): Expression of Dbx1, Neurogenin 2, Semaphorin 5A, Cadherin 8, and Emxl distinguish ventral and lateral pallial histogenetic divisions in the developing mouse claustroamygdaloid complex. J Comp Neurol 474:504-523.

-Nagano T, Morikubo S, Sato M (2004): Filamin A and FILIP (Filamin A-Interacting Protein) regulate cell polarity and motility in neocortical subventricular and intermediate zones during radial migration. J Neurosci 24: 9648-9657.

Nery S, Fishell G, Corbin JG (2002): The caudal ganglionic eminence is a source of distinct cortical and subcortical cell populations. Nat Neurosci 5:1279-1287.

Paxinos G, Ashwell KWS, Tork I (1994): Atlas of the Developing Rat Nervous System, ed 2. New York, Academic Press.

Paxinos G, Watson C (1997): The Rat Brain in Stereotaxic Coordinates, compact ed 3. New York, Academic Press.

-Pilz DT, Matsumoto N, Minnerath S, Mills P, Gleeson JG, Allen KM, Walsh CA, Barkovich AJ, Dobyns WB, Ledbetter DH, Ross ME (1998): LIS1 and XLIS (DCX) mutations cause most classical lissencephaly, but different patterns of malformation. Hum Mol Genet 7:2029-2037.
Puelles L, Kuwana E, Puelles E, Bulfone A, Shimamura K, Keleher J, Smiga S, Rubenstein JL (2000): Pallial and subpallial derivatives in the embryonic chick and mouse telencephalon, traced by the expression of the genes Dlx-2, Emx-1, Nkx-2.1, Pax-6, and Tbr-1. J Comp Neurol 424:409-438.

Rainnie DG, Asprodini EK, Shinnick-Gallagher P (1993): Intracellular recordings from morphologically identified neurons of the basolateral amygdala. J Neurophysiol 69:13501362.

Rakic P (1971): Guidance of neurons migrating to the fetal monkey neocortex. Brain Res 33: $471-476$

Rakic P (1972): Mode of cell migration to the superficial layers of fetal monkey neocortex. J Comp Neurol 145:61-83.

Ramos RL, Bai J, Loturco JJ (2006): Heterotopia formation in rat but not mouse neocortex after RNA interference knockdown of DCX Cereb Cortex 16:1323-1331.

Reiner O, Carrozzo R, Shen Y, Wehnert M, Faustinella F, Dobyns WB, Caskey CT, Ledbetter DH (1993): Isolation of a Miller-Dieker lissencephaly gene containing $\mathrm{G}$ protein betasubunit-like repeats. Nature 364:717-721.

-Sasaki S, Shionoya A, Ishida M, Gambello MJ, Yingling J, Wynshaw-Boris A, Hirotsune S (2000): A LIS1/NUDEL/cytoplasmic dynein heavy chain complex in the developing and adult nervous system. Neuron 28:681-696.

-Shu T, Ayala R, Nguyen M-D, Xie Z, Gleeson JG, Tsai L-H (2004): Ndell operates in a common pathway with LIS1 and cytoplasmic dynein to regulate cortical neuronal positioning. Neuron 44:263-277.

Sidman RL, Rakic P (1973): Neuronal migration, with special reference to developing human brain: a review. Brain Res 62:1-35.

Tabata H, Nakajima K (2003): Multipolar migration: the third mode of radial neuronal migration in the developing cerebral cortex. J Neurosci 23:9996-10001.

-Tamamaki N, Fujimori KE, Takauji R (1997): Origin and route of tangentially migrating neurons in the developing neocortical intermediate zone. J Neurosci 17:8313-8323.
Tamamaki N, Nakamura K, Kaneko T (2001): Cell migration from the corticostriatal angle to the basal telencephalon in rat embryos. Neuroreport 12:775-780.

Tanaka T, Serneo FF, Higgins C, Gambello MJ, Wynshaw-Boris A, Gleeson JG (2004): Lis1 and doublecortin function with dynein to mediate coupling of the nucleus to the centrosome in neuronal migration. J Cell Biol 165:709-721

Tole S, Remedios R, Saha B, Stoykova A (2005): Selective requirement of Pax6, but not Emx2, in the specification and development of several nuclei of the amygdaloid complex. J Neurosci 25:2753-2760.

-Tsai J-W, Chen Y, Kriegstein AR, Vallee RB (2005): LIS1 RNA interference blocks neural stem cell division, morphogenesis, and motility at multiple stages. J Cell Biol 170:935945.

Tsai L-H, Gleeson JG (2005): Nucleokinesis in neuronal migration. Neuron 46:383-388.

Tsukada M, Prokscha A, Oldekamp J, Eichele G (2003): Identification of neurabin II as a novel doublecortin interacting protein. Mech Dev 120:1033-1043.

Tsukada M, Prokscha A, Ungewickell E, Eichele G (2005): Doublecortin association with actin filaments is regulated by neurabin II. J Biol Chem 280:11361-11368.

Washburn MS, Moises HC (1992): Electrophysiological and morphological properties of rat basolateral amygdaloid neurons in vitro. J Neurosci 12:4066-4079.

Wichterle H, Turnbull DH, Nery S, Fishell G, Alvarez-Buylla A (2001): In utero fate mapping reveals distinct migratory pathways and fates of neurons born in the mammalian basal forebrain. Development 128:3759-3771.

Yu J-Y, DeRuiter SL, Turner DL (2002): RNA interference by expression of short-interfering RNAs and hairpin RNAs in mammalian cells. Proc Natl Acad Sci USA 99:60476052 . 